\title{
体重増加不良で発見された食道異物症例
}

\author{
高田 弥生, 佐 野 光仁
}

\section{Esophageal Foreign Body Found by That Gaining Weight Wasn't Good}

\author{
Yayoi Takata, M.D. and Mitsuhito Sano, M.D. \\ Department of Otorhinolaryngology, Osaka Medical Center and \\ Research Institute for Maternal and Children Health, Osaka
}

A child with mental retardation, who could not report to subjective symptoms, came to our institute because of failure to gain weight. A foreign body shadow of a safety-pin was found accidentally in his chest with a plain X-ray.

This patient was a 16-month-old male, and the foreign body shadow of an open safety-pin was found at the first cervical constriction of the esophagus. The sharp end of the safety pin was upwards.

He was admitted to emergency, and we attempted to remove the safety-pin by direct esophagoscopy under general anesthesia. However, the pin was buried in the wall of the esophagus, and we gave up because of the danger involved. The next day we performed an incision of the neck and removed the safety-pin.

Key words : safety-pin, direct esophagoscopy, incision of the neck, failure to gain weight

\section{I .はじめに}

食道異物の場合，何らかの自覚症状を伴うこ とが多い。乳幼児は明確な言葉で症状を訴えら れない場合も多く, 嬩下困難, 発熱, 嘔吐, 流 涎過多，摂食量減少，激しい啼泣，喘鳴などの 症状を現すことで異物誤臙の事実がわかる。

今回われわれは, 精神発達の遅れがあり体重 増加不良にて当センターを受診し, 精査の目的 で撮影された胸部 X-Pにて安全ピン食道異物 が発見された症例を経験したので, 若干の文献 的考察を加えて報告する。

大阪府立母子保健総合医療センター耳鼻咽喉科 別刷請求： $=590-02$ 大阪府和泉市室堂町840 大阪府立母子保健総合医療センター耳鼻 咽喉科 高田弥生

投稿受付：1997年 1 月31日

\section{II . 症 例}

症 例：1歳 4 力月, 男児

主 訴: 体重増加不良

既往歴：分婏麻痺

現病歴：1996年 5 月31日体重増加不良のため 当センター第 1 小肾内科受診した。精查の目的 で撮影された胸部 X線にて食道第 1 狭窄部に安 全ピンが発見された。図 1 に胸部正面単純 $X$ 線 写真を, 図 2 に胸部側面単純X線写真を示す。 安全ピンの先が右側上向きに開いている。肺野 はX線透過性良好で肺炎所見, 気腫像, 膿瘍像 などは認められない。これより緊急入院となっ た。血液検査では白血球数 $14,200 / \mathrm{mm}^{3}, \mathrm{CRP}$ $0.4 \mathrm{mg} / \mathrm{dl}, \mathrm{GOT} 18 \mathrm{IU} / \mathrm{l}, \mathrm{GPT} 13 \mathrm{IU} / \mathrm{l}$, 赤血 球数 460 万 $/ \mathrm{mm}^{3}, \mathrm{Hb} 11.2 \mathrm{~g} / \mathrm{dl}$, Ht $34.9 \%$ で 白血球数值と CRP 值の軽度上昇がみられた。 入院時体重7,220 g で，これは 1 力月前の体重 


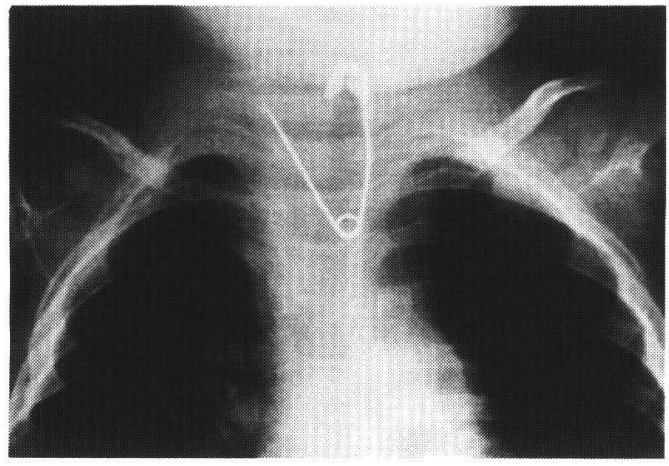

図 1 胸部正面単純 $X$ 線写真

針先が上を向いて安全ピンは開いたままである。

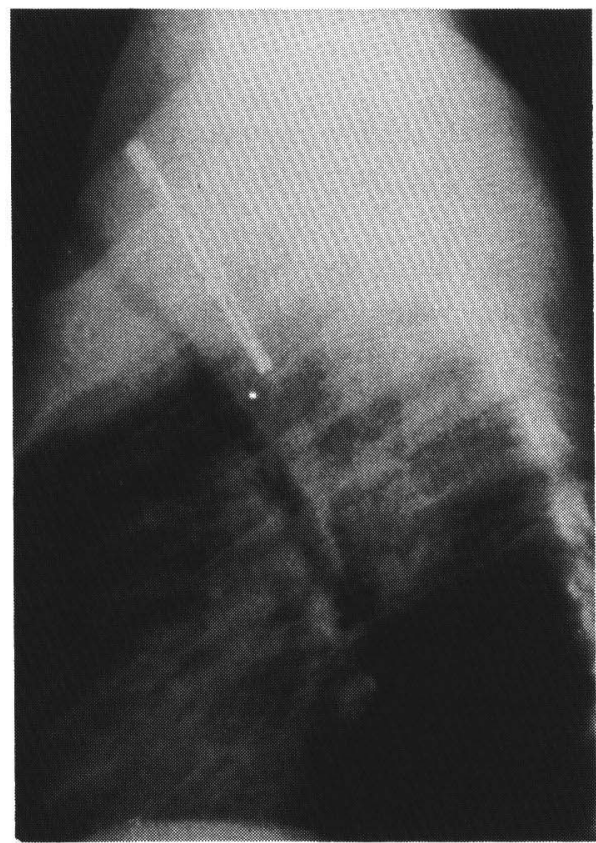

図 2 胸部側面単純X線写真

より $110 \mathrm{~g}$ 減少していた。全身麻酔下に放射線 透視で安全ピンの位置を確認しながら硬性食道 鏡を挿入し，安全ピンの摘出を試みたが，異物 介在部位の粘膜が浮腫状で，無理に摘出する際 の危険性を考慮し摘出を断念した。

手術所見：1996年 6 月 1 日頸部食道外切開術 を施行した。手術所見は右前頸部に横切開を加 え, 広頸筋を切開し胸鎖乳突筋前面の層で上下 に剥離し, 胸鎖乳突筋の前縁を剥離し側方へ偏 位させた。この間隙より内頸静脈を剥離 taping

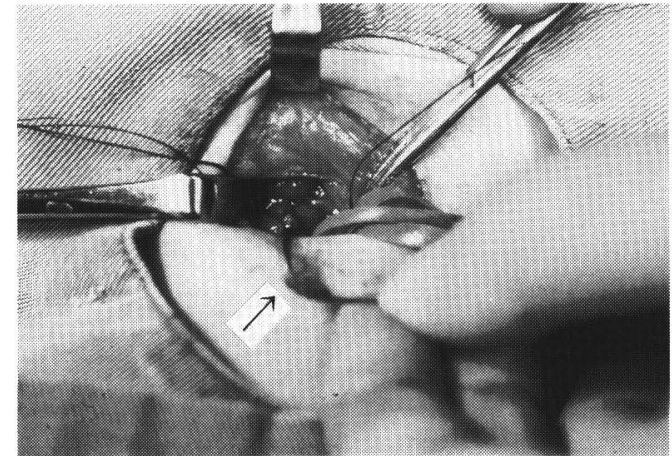

図 3 術中所見

動静脈を taping して行った。かが食道に介在してい る安全ピン。

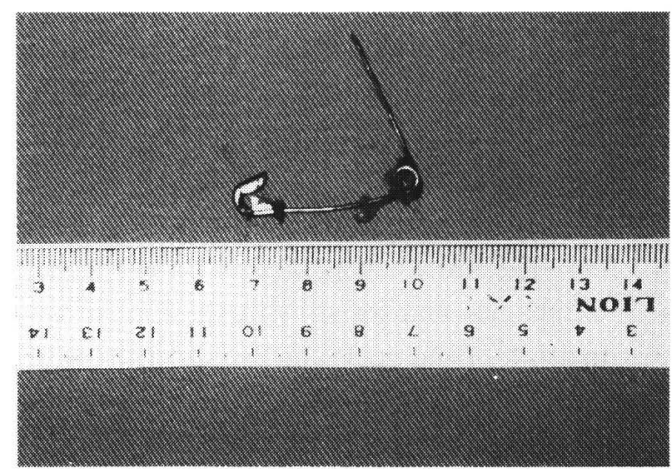

図4 摘出した安全ピン

長さは $3.5 \mathrm{~cm}$ で安全ピンは錆びておう，長期間食道 粘膜に埋もれていたことを示す。

し, 頸動脈も剥離 taping した。甲状腺の右縁を 剥離し前方に牽引すると気管の裏側に食道を認 めた。イメージインテンシファイアーにより安 全ピンの位置を確認し, 鉗子でピンの先を触知 してそのまま把持し，摘出した。食道粘膜を縫 合し瘦孔がないことを内視鏡で確認した後ドレ ーンを留置して閉創した(図 3 )。摘出した安全 ピンは長さが $3.5 \mathrm{~cm}$, 表面が錆びており長期間 食道粘膜に埋もれていたことを示していた（図 4 )。

術後経過：経中心静脈栄養による栄養管理を 行い, 絶飲絶食として ICUにて 3 日間人工呼吸 管理を全い, 安静を保った。術後10日目に上部 消化管造影を行い，造影剂の漏れがなく食道の 運動が良好なことを確認した上で経口捸取を開 始した。術後11日目にドレーンを抜去し, 術後 


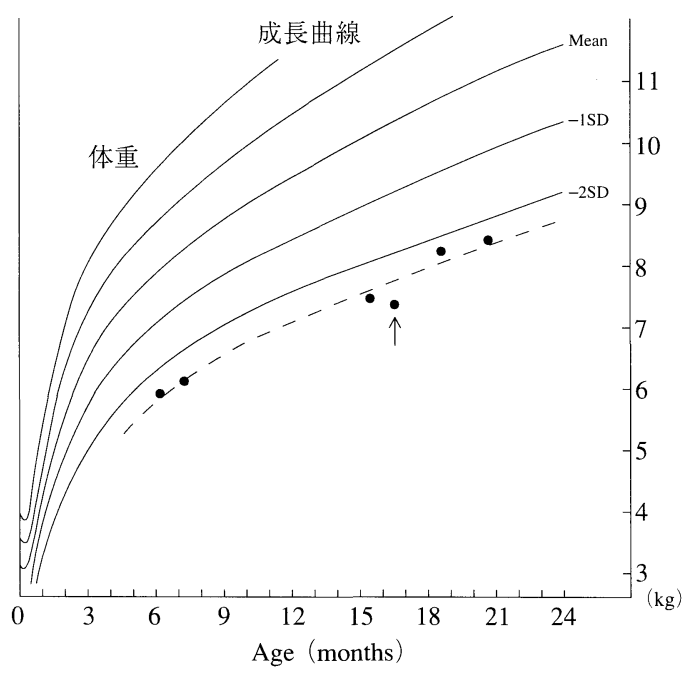

図 5 成長曲線

$\rightarrow$ 入院時の体重である。1 カ月前より $110 \mathrm{~g}$ 減少 している。安全ピン摘出後は順調に体重が増加して いる。

15日目に退院となった。以後, 体重は順調に回 復した（図 5 )。

\section{III. 考 察}

乳幼児の食道異物症にみられる主訴は鯂下困 難, 喘鳴, 発熱, 嘔吐, 激しい啼泣, 流涎過多, 攝食量減少などである。合併症として，食道穿 孔をきたし気管食道瘻, 縦隔洞炎, 肺膿瘍など を起こすことがある。今回の症例はこういった 症状はみられず, 体重増加不良にて当センター 第 1 小児内科を受診した際に偶然発見された。 成長曲線と摘出された安全ピンが錆びていたこ とより 1 カ月以上前に飲みこんだと考えられ る。精神発達遅滞のある览であり，そのため食 欲不振の原因が明確にならなかったと考元られ る。

検査は頸部・胸部単純 $\mathrm{X}-\mathrm{P}$ 二方向を必要とす る1)。X線非透過性異物の場合は診断は容易で ある。しかし椎体前軟部組織の状態, 頸部や縦 隔洞の気腫，また時には気胸などの所見がみら れることがある。気管後部軟部組織陰影の拡大 がみられれば, 咽喉膿瘍あるいは血腫を考える。 Pasquariello ら²)は小児で説明のつかない嚥下 障害や呼吸障害などがあれば，胸部および頸部 X線検査の必要があると述べている。食道透視
造影検査も必ず行うべき検査である。異物の有 無, 介在部位, 大きさ，輪郭および合併症の有 無を術前に必ず予知し，あらゆる可能性に対処 できるよう準備しなければならない。しかし直 達鏡検査については，Jackson³) は見るだけを 目的とした食道鏡検査を戒めている。異物摘出 を目的としなければならない。

摘出時の麻酔は気管内挿管による全身麻酔が 安全かつ摘出を容易ならしめる方法である。気 管内挿管していると食道鏡や異物による気道へ の圧迫がなく, 嘔吐した場合には吐物の気管内 誤飲が防げる。精神的肉体的苦痛がなく, 筋は 弛緩されているので食道鏡は挿入されやすく, 粘膜に刺入されていても刺入点の確認, 抜去, 摘出は一般に容易である。

食道粘膜刺入異物摘出法としてへラや食道拡 張器を利用する方法, カフ付き食道鏡4 による 摘出法, 上部食道鏡に固定器を用いる方法 ${ }^{5}$, ビ ニール管に割をいれて尖鋭部を保護し摘出する 方法 ${ }^{4)}$, 尿道バルーン・カテーテルを利用する方 法6)，頸部食道外切開術などがある。

義歯, 魚骨片, 針などは頸部外切開術が必要 なことが多い。開放した安全ピン ${ }^{7)}$ は最も摘出 に困難な食道異物の一つだといわれている。閉 じた安全ピンや, 針先が下向きのものは摘出に それほど困難をきたさない。針先が上向きで開 放した場合, 強引に引き上げると強力な spring の作用でより広がり，針先は食道壁を容易に穿 通する。柴田ら ${ }^{8)}$ は鏡管先端を側方に押し食道 腔を広げ，異物を横にして針先をわずかに粘膜 に刺入させ，これを軸として回転させ，針先が 下向き, spring を先端とし, そのまま鉗子を強 くひき, 鏡管内に安全ピンを取り込み摘出して いる。今回の症例でも硬性食道鏡を挿入し安全 ピン摘出を試みたが, その部分の粘膜が浮腫状 であり，無理に摘出して食道壁に穿孔を起こす 危険性を考慮して摘出を断念した。

術後の合併症として松原ら ${ }^{9)}$ は義歯摘出にお いて硬性食道鏡を使用した際, 第一狭窄部で強 い抵抗あり，義歯を食道鏡とともに摘出し，翌 日, 頸部皮下気腫, 縦隔気腫の増強を認め, 縦 隔洞炎をひき起こした例を報告している。食道 損傷の恐れがある場合は, 頸部食道外切開術を 積極的に施行するべきであろう。頸部食道外切 
開の適応としては，1）食道壁に深く刺入して いる場合あるいは埋没している場合，2）食道 膿瘍, 食道穿孔, 縦隔洞炎, 気管浮腫などを併 発している場合，3）異物摘出が困難な場合な ぞがあげられている10,11)。

食道異物による食道穿孔は比較的稀な疾患で あるが，その死亡率は約20\%前後であるという 報告がある12)。好発部位に関しては, 斉田ら ${ }^{13)}$ は食道異物全体が食道第一狭窄部位に多いのに 対し，異物による食道穿孔の場合はむしろ第二 狭窄部位に多いと報告している。食道異物摘出 後は胸部 X-P を撮影して食道穿孔による皮下 気腫, 縦隔気腫, 胸水の存在がないか確認する ことが大事である。

Appleton ら ${ }^{14)}$ は頸部食道穿孔では皮下気腫 が, 胸部食道穿孔では縦隔気腫, 胸水が, 腹部 食道穿孔では横隔膜下の free air が認められる ことが多いと報告している。穿孔の部位を正確 に知るには食道造影が必要であろう。また経口 摂取開始前には, 食道造影で造影剤の漏出がな いことを確認することも必要である。

手術後の治療で重要なことは, 全身的には十 分な栄養管理, 適切な化学療法, 局所的には排 膿であると松原 ${ }^{9)}$ は述べている。われわれは筋 弛緩剤の臭化ベクロニウムや鎮静剤のミダゾラ ムを用いて安静を保ち, 縦隔洞炎や頸部膿瘍の 発症を避け，食道壁の閉鎖を促進させるように した。栄養は今回は中心静脈栄養を用いたが, 鼻腔栄養や胃㿉造設 ${ }^{15)}$ による栄養管理を行う 場合もある。

\section{IV. 結語}

精神発達遅滞があり，体重増加不良を主訴に 当センターを受診し, 安全ピン食道異物を偶然 発見された 1 歳男児について報告した。全身麻 酔下にイメージインテンシファイアーを併用 し, 頸部食道外切開術にて安全ピンを摘出する
ことに成功した。

本論文の要旨は第48回日本気管食道科学会学術講 演会（1996年11月14日，15日，大阪市）において発 表した。

\section{文献}

1）大戸武久, 瀧野賢一, 大西俊郎：食道骨異物の 診断について。 日気食会報, 29：215-220, 1978.

2 ) Pasquariello, P.S., et al. : Cyanosis from a foreign body in the esophagus. Clin. Pediatr., $14: 223-225,1975$.

3 ) Jackson, C. (小野 譲訳) : 気管食道科診療の 実際, 学術書院, p. 238, 1950.

4 ）荒牧 元・他：カフ付き食道鏡により摘出した 食道異物例 (義歯)。耳鼻, $17: 44-46,1971$.

5 ) 斎藤誠次, 小野 譲, 斎藤成司・他：固定器を 使い上部食道鏡を用いた尖鋭異物摘出法。日気 食会報, $23 ： 273,1972$.

6 ）新井健之, 奈良圭司, 北島政樹・他：尿道バル ーン・カテーテルによる食道異物剔出の経験. 日気食会報, $21 ： 129-134,1970$.

7 ) Jackson, C. : Bronchoscopy and Esophagoscopy, II ed p. 238, W.B. Saunders Co., Philadelphia $\cdot$ London, 1927.

8 ）柴田浩一，松元一郎：開放した安全ピン食道異 物の摘出.耳鼻, $22: 100-102,1976$.

9 ）松原茂規，宮田英雄，曾賀野悟史・他：食道鏡 使用後の縦隔洞炎の 2 治験例. 耳鼻臨床, 83 : 1583-1589, 1990.

10）井上鐵三：食道外切開による異物除去術.耳鼻 咽喉科手術アトラス下巻, 医学書院, 東京, 1979 .

11）松永喬：食道異物. JOHNS, $8: 337-345$, 1992.

12）宗弘，松尾信昭，野津史博・他：鷄骨によ る食道穿孔の一治験例. 日消外会誌, 21：74-77, 1988.

13）斉田晴仁，調所廣之，岡本和人・他：カーテン レールにより食道穿孔を生じた食道異物 1 症 例. 日気食会報, $40 ： 344-349,1989$.

14） Appleton, D.S. : Perforated esophagus review of twenty-eight consecutive cases. Clin. Radiol., $30: 493,1979$.

15）中村 豊：食道鏡による食道穿孔に続発した左 膿気胸の治験例. 外科診療, $15 ： 751-755,1966$. 